\title{
A Few Words about the Recently Published Anglo-Saxon Poem, the First Edition of Beowulf
}

\author{
Translated and Annotated
}

\author{
Mark Bradshaw Busbee
}

In July and August of 1815, Grundtvig published "Et Par Ord om det nys udkomne angelsaxsiske Digt" (A Few Words about the Recently Published AngloSaxon Poem) in Nyeste Skilderie af Kjøbenhavn (The Latest Scenes of Copenhagen), nos. 60, 63, 64, 65, and 66. ${ }^{\mathrm{i}}$ The article responded primarily to an anonymous review in Dansk Litteratur-Tidende (Danish Literary Times) of the first edition of Beowulf, which had been published that spring by Grímur Jónsson Thorkelin. ${ }^{\text {ii }}$ Grundtvig was dissatisfied with the edition, particularly because the Old English text was accompanied by a Latin paraphrase that was confusing and inconsistent and, as he makes clear in the article, often wrong. But it was the anonymous review that received the full force of Grundtvig's sharp critique. The reviewer (thought to be the editor Peter Erasmus Müller) blindly followed the Latin paraphrase and, as a result, offered incorrect explanations of the poem's contents. ${ }^{\text {iii }}$ Grundtvig set out to correct the reviewer's and the editor's mistakes by working through the poem's plot and by offering sample translations in Danish. The result was the first, mostly accurate published account of the poem's plot and characters and one of the first deliberations over the poem's artistic value. These achievements establish Grundtvig's article as a milestone in Beowulf scholarship; however, likely due to Grundtvig's style of writing - his long, meandering sentences and tendency to make obscure literary and biblical references - the article has not previously been translated into English in its entirety. ${ }^{\text {iv }}$

The following translation is therefore an effort to make this groundbreaking article available to an international audience with interest in Beowulf or Grundtvig or both. Footnotes have been included for quick access to points about Beowulf and endnotes have been included for information about secondary 


\section{Mark Bradshaw Busbee}

source materials mentioned. Grundtvig's own endnotes are placed at the end of each installment, where they appear in the original text. Grundtvig's practices of producing Old English words and phrases in small capital letters and of referring to Thorkelin's edition with page numbers in parentheses have been maintained. All references to Beowulf included in the notes are to the edition by Fulk, Bjork and Niles (2009).

The source text for this translation is the edition of "Et Par Ord" created by Vibeke Arendse Pedersen for Grundtvigs-Værker (grundtvigsværker.dk). Pedersen has played an integral role in the translation work by helping to elucidate complicated passages, ones typical of Grundtvig's highly allusive style. Special thanks also go to S. A. J. Bradley and Robert E. Bjork, for their generous, expert suggestions, particularly about how best to render Grundtvig's highly rhetorical prose and his folksy poetry in English.

\section{A Few Words about the Recently Published Anglo-Saxon Poem}

No. 60, Col. 945-52 Anyone who still loves ancient Denmark and the commemoration of our forefathers has surely seen with pleasure that the ancient Anglo-Saxon poem about Danish deeds, which for so many centuries lay buried away on English bookshelves and which was only with difficulty saved like a brand from the fire, now finally has been published by the hand of Mr. State Councilor Thorkelin, with the generous assistance of Mr. Privy Councilor Bülow. ${ }^{\mathrm{vi}}$ Many readers might justifiably complain that the translation is in Latin and ask how long we shall continue to publish the ancient memorials of the North for foreigners at Denmark's expense; however, in this case such a complain would have less basis, for a poem such as this must in the first instance be published for scholars in all countries and does not need to appear before the Danish people except in its appealingly poetic form. On the other hand, it would have been appropriate for either the editor or another to explain the poem's contents in the mother tongue and to have pointed out what we all could immediately appreciate about its poetic and historical worth; and since the publisher has not fulfilled that wish either in Latin or in Danish, I decided to do that to the best of my ability. This was not, however, so easy a task, as I noticed right away that it would be pointless to follow the Latin translation, which in many places is clearly wrong and in many other places more obscure than the text itself, and I had therefore to immerse myself | Col. 946 in the original language. To my great amazement, Litteratur-Tidende [The Literary Times] No. 26 
already reviewed the poem and enumerated contents of nineteen songs, as $\operatorname{did}$ No. 27 of the rest. ${ }^{\text {vii }}$ Before I laid hands on the magazine, I realized how impossible it was that a reviewer, even if he were proficient in the language, could in so short a time have read through and thought through the poem, as one certainly should before one can give a public account of a such a monument. But how could I be anything but infuriated to see that here a reviewer put himself in the judgment seat without, one must conclude, understanding a single word of Anglo-Saxon. Now, to give a contents list like that certainly did not take a long time; for where the Latin translation makes any sense, it is followed blindly, and where it makes none, the blame is cast on the poem's obscureness. Yes, indeed, the skald is even accused of having contradicted himself in the story of Hygelāc's death, ${ }^{1}$ although it is certainly not his fault that the translator and the reviewer mix events together and change the rulers' names - Hrēðel, Herebeald, Hæðcyn, Heardrēd - to insignificant adjectives. ${ }^{2}$ But what sort of behavior is this? Is this the erudition and criticism that we boast so much about? Is this the way that such memorials of heathen times shall be made known and spoken of in Denmark, so that foreigners shall point their fingers at us as those who praise and judge what we do not understand?

If what is said here about the translation and review is true - and I shall prove it - | Col. 947 then it is clear that a new account of the poem's contents would be by no means superfluous; but since I am still far from understanding everything as well as one ought to understand what one intends to communicate to others, and since, even so, that review certainly must not come unchallenged before the eyes of foreigners, I want as briefly as possible here to note what is of importance in the parts that I do understand, that in the review have been partly omitted, partly incorrectly represented. Doubtless, people will not enjoy being reprimanded by me; on the whole, I would really rather not quarrel over an issue that is

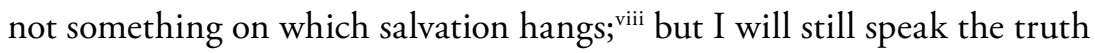
when the issue is not entirely negligible and will then leave it to those concerned to decide whether they will deny what is clear to everybody in Europe who understands what is spoken about here.

1 In the poem Hygelāc is king of the Geats and the uncle of the protagonist, Beowulf. He is killed in a raid of Frisia (Beowulf, lines 2913-19).

2 Hrēðel is Hyg gelāc's father and Beowulf's grandfather; Herebeald is Hrēðel's eldest son and Нæðcyn is his second son. Heardrēd is Hygelāc's only son. 
Now to demonstrate simultaneously both what the tone of this glorious poem is like and how seriously the translator and reviewer have misunderstood even its opening passage, I offer here a translation of it, which naturally cannot be literal since it is in poetic form, but I vouch for its essential correctness. However, in order to make it properly comprehensible, I must make a preliminary observation. Just as one finds frequently in the Anglo-Saxon genealogies, albeit in various places, a Scef, Sceaf, Seaf, whom the C[h]ronicon Saxonicum (page 77) makes the fourth son of Roe, so also he is sometimes referred to as the father of Scyld, whose identification with Skjold cannot be doubted. Also, in Æthelweard, Matthew of Westminster and Symeon of Durham, ${ }^{\mathrm{ix}}$ an exceedingly strange legend is told about him, namely, that he, as a child sleeping in a sheaf of grain and surrounded by weapons, came drifting alone on a ship to an island in the ocean by the name of Skani or Skandalis where the inhabitants received him as a miracle, nourished him with all diligence, and took him as their king. One sees that the present skald has transferred this legend to Scef's Son, Scyld, and since in our ancient legends we find no Scef then he must have got this name from the sheaf of corn which is called in Anglo-Saxon SCËAF, and since he therefore would most reasonably have to be called Scefing (Scef's son), we have here undoubtedly the legend in its native original Danish form. So sings the old skald: ${ }^{3}$

\section{| Col. 948}

Of majesties bold

From the days of old, who the kings' royal thrones

With glory adorned

In Dannemark's land;

Of those warriors proud, Who bravely wrought deeds, I truthfully sing.

Now first must be told Of the Skefing-son Skjold:

3 The translation that follows is of Beowulf, lines 1-52. 
He battled with might

That warlord so bold

Gainst many a foe

For strongholds and lands,

And victories he won.

His courage and realm

They grew hand in hand,

As the years flowed by;

His fame and fortune

So surely they grew,

That all those who dwelt

Round whales' broad domain,

Him had to obey,

And with a bow give

Both feasting and drink.

It remains to tell

Of this king so good:

That warriors sturdy

Sprang out from his blood,

And in his honor

They carry always

The Skjoldunge name. (1

3

The Lord God who knew

All Denmark's sore need

Sent there such a king

As Denmark's relief,

| Col. 949 And allowed him long

Upon his king's throne

To see over meadows

The radiant sun.

Upon royal seat

He shared out with joy

Gems costly and fine

Among his warriors;

Nor furnished he meanly 
Magnificent drink,

So tribute they vowed him,

Those warriors on bench, And followed with joy

That lord so revered, And the Skjoldung-Tribe

By splendid offspring

So high 'neath the hilltop,

So widely it spread,

So fair in the grove.

4

Thus do the kings learn

With gold and honors

To win the best warriors

To forge a firm bond!

Then, firm, the old ones

Gather themselves round

On the day of storm,

Surround so boldly

With bucklers so bright

Their lord in battle.

No giver of gold

Can thrive in his hall

When feats fit for heroes

Flourish not in the field. (2

5

When Skjold had gone hence,

At death-time, to Roe,

There flocked in the field

So faithful a crowd.

| Col. 950 So in hand took they

The loving retainers

The corpse of King Skjold;

To sea-shore they bore 
In sorrowful swarm

That great lord so bold;

The corpse out they brought,

As he himself bade,

When words he still said

Upon his high throne,

And ruled with mildness

The lands far and wide,

So many a good day.

6

Then took the bold ones

The king's royal ship

With ring adorned prow,

Which, ready to sail,

With shields shining bright

At port lay prepared.

In the ship's embrace

They gave then that lord

Who bore in his life

The fairest of names;

By the mast they laid

Their beloved king's corpse,

And gave him the treasures,

A shield-wall so rich

That hardly one tale

Have I heard much like

Of treasure and ship.

7

Beside the king's cloak

Lay all kinds of weapons:

The axes so stout

And war-shirts so thick.

Gems precious and plenty

Were laid in his arms; 


\section{Mark Bradshaw Busbee}

On the voyage long

They must, in that keel,

On the roaring wave,

With the great king go.

| Col. 951 This lord they would send

Equipped from the land,

With gifts so worthy,

As when, over the sea,

Miraculously he

Was driven by God

To Dannemark's land. (3

8

And now the fair flag

That people so bold

set to flutter stately

right over King Skjold;

So must they, grieving,

Let the ship slip free,

To be driven onwards

By wind and by chance.

Away sailed the ship

Upon waves of blue,

Leaving heroes in ranks

To stand on the shore

With sighs and lamenting;

And he never returned,

Indeed, no one truly

Can say that he knows

Where over the sea

The ship went hence,

Where received and found

The mighty king's corpse was,

If any found joy with

That cargo so rich. 
Now, when one sees that in the review, just as in the Latin translation, there is not a trace of Skjold's funeral, one must believe one of two things, either that I have made it up on my own or that the reviewer and the editor did not know as much enough Anglo- | Col. 952 Saxon as one can learn in a fortnight, if one knows Icelandic; and until the former is proven, surely the latter stands true. However, I would rather conclude with the observation that even if this introduction were the most superb part of the whole poem, we might still call it a great discovery; for surely, the legend of Scyld's funeral is a counterpart to that of Fredegod [King Frothi III] ${ }^{4}$ and it breathes the love that was the Danes' heritage. ${ }^{\mathrm{x}}$ Yes, it is like a prediction of the incorruptibility of the Skjoldung stock; for Skjold's tomb is nowhere to be found, his shadow hovers over the deep-hued ocean, Dannebrog is his memorial stone and Denmark's heart is his mausoleum.

1) It should be noted that the meaning of these lines is debatable and that it is not stated here that his descendants were called Scyldings, but since it is stated in the poem as a whole, I did not hesitate to insert it for the sake of completeness.

2) I dare not claim to have precisely caught the meaning of the last lines in this speculative rendition but there again, as one readily sees, it does not say very much.

3) The lines that contain this speculative rendition are also obscure; however, I believe I have caught the meaning that relates to ancient oral legends, and that if one has the right with the Latin translator to take "DYDON" and "ONSENDON" for third-person singular, then there can be no question whatsoever, only on this point I remain in doubt. ${ }^{5}$

\section{No. 63, Cols. 998-1002}

Then there was upon the strongholds the love of Beowulf of the Scyldings, the people's king (who, as an old man, quitted the world), when the great

\footnotetext{
4 The life of Frothi III is the topic of Book V of Saxo Grammaticus' History of the Danes. Saxo represents Frothi both as a victorious leader who built a Danish empire and as a capable lawgiver who established lasting peace and prosperity. 5 The verbs "dydon" and "onsendon" are third-person plural preterite verbs.
} 
Healfdene was born to him. ${ }^{6}$ So begins the content list of the first song in the review, and with this there are nearly as many mistakes as words, even one more than in the Latin translation. That the translator, here and in the introduction, has regarded Beowulf as a name for the son of Scyld, could easily happen, though upon closer reflection one sees that Beowulf here, like Hroðulf (page 90), ${ }^{7}$ is only a honorific name and that the Scyldings' Beowulf with whom the first song begins is no other than Scyld himself; but what is entirely improper is that in order to say something about the Beowulf of his own devising, Mr. State Councilor [Thorkelin] has launched an open assault against the plain words of the text. Granted, some of the words are obscure, but it clearly says there that, according to the people's account (FOLCUM GंEFR $Æ \dot{G E}$ ), many years passed on earth before the Scylding's Beowulf, High Healfdene was born (onwoc), and it is no insignificant matter. It is historically important whether the old skald is reckoning Scyld, Beowulf and Healfdene as sons succeeding fathers or whether he is saying that there was a long interval from Scyld to Healfdene, as there must be, according to our other ancient legends. Nor is it unimportant whether the skald is giving us Beowulf as a Danish royal name. Many things make clear that he does not, but it is not important enough here to develop the point, and I will only note that the first song conforms in the most unforced way to the prologue when, as one with good reason one can, one translates: "Now was then the Scyldings' Beowulf, the beloved mighty king, was then buried, and as they say, many anniversaries passed, before the great Healfdene arose after him." (4

| Col. 999 I do not want to dwell on trifles and disputations; I note only that all the wrangling about the name Hjort [hart; deer] for Hroðgar's hall was surely just splitting hairs, partly because heorth is "home" $(\text { Heerde })^{8}$ and partly-it it seems clear to me-that Hjort [hart; deer] is in any case stated to be the hall's poetic name, presumably from the word hiorta (merry, cheerful).

\footnotetext{
${ }^{6}$ Here Grundtvig presents the birth of Healfdene as the lasting manifestation of the good king Scyld's love for his people.

7 Grundtvig is incorrect here: the poem does mention a son of Scyld named Beowulf (Beowulf, line 18), and Hroðulf is actually the name of a character (a nephew of Hroðgar) mentioned at line 1017.

8 There is no Old English word in this form. Grundtvig is working from Thorkelin's incorrect text.
} 
There is nothing significant to note about the content of the second song [lines 115-188], which is about Grendel's intrusion in the hall and the Danes' grief, except that the skald, by naming Vig as the Danes' pagan god, ${ }^{9}$ strengthens the testimony of Ælnoth (Chapter 23) - a source that some scholars don't want to acknowledge. ${ }^{\mathrm{xi}}$

The third and fourth song [lines 189-257, 258-319] about Beowulf's journey from Gothland to Denmark and his reception by the coastguard comprise one of the most poetic pieces in the poem and have an Odyssean beauty as unexpected as it is captivating. In the review there surely should have been said something more and something other than that the coastguard asked in a long speech who the strangers were and what they wanted, and that Beowulf answered in the same long-winded way, because in reading this one has the least expectation of hearing something intensely beautiful. Still, one should certainly not quarrel over matters of taste and pleasure. On the other hand, the reviewer should have seen that the fire which he has the coastguard light is only a strange chimera, since in the poem it only states that he became curious when he saw the strangers: HINE FYRWYT BRÆC [curiosity gripped him], an expression that in the same poem (149) is translated correctly but in another place (207) is completely confusedly, as: domesticos ensis rabidus subegit [the raging sword subjected the citizens]. Indeed, in this poem it is not unusual that the very same word is translated in the entirely opposite way, but such things a reviewer should see, or at least learn that it was not enough to rely on Latin and to allow Angari ignes [bonfire] to parade in the index rerum, when they don't have further authority for it. The savvy reader sees that it is not altogether unimportant whether the old skald mentions lighthouses or beacons as common in ancient Denmark and this must excuse my delay over these words. The reviewer's proclamation that the coastguard asked the Goths to leave the ships is completely incorrect and not even allowed in the Latin, for he commanded them precisely to stay by the ships until they got a favorable wind and could again sail home to Gothland. | Col. 1000 It is unclear, on the other hand, what made Beowulf decide all the same to go ashore. It seems to me that here the text mentions a deity's, pre-

9 The name "Vig" appears nowhere in Beowulf. Grundtvig follows Thorkelin who mistakenly separated the compound word "wigweorthung" (honor to idols) at line 176 into "Wig weorthung" and glossed "Wig" as a god of war (Thorkelin 208). 
sumably Hilda's, revelation in a golden airship, promising the hero both to protect him and guard his ships, but I will certainly not publish anything about which I myself have even the slightest doubt. ${ }^{10}$

In the fifth song [lines 320-370], which describes Beowulf's song and declaration in the hall of Hroðgar, I find nothing important to note, but about the sixth, which contains Hroðgar's speech about Beowulf and what he says to him, I must speak a few words. It is said that Hroðgar is made to say of Beowulf that he had come with gifts and three hundred men, when to the contrary he says only that the sea-folk have told him about Beowulf, that he had the strength of thirty men, something which fits with his being able to do battle with Grendel. As far as the gifts are concerned, if such can be understood by GIFSCEATTAS, they are more important than the reviewer thinks because this reference could readily be used in a debate about whether the Goths had to pay tribute to the Danes or the Danes to the Goths. I must further note that the reviewer's conclusion about the three-hundred men for the small range of Beowulf's fifteen is utterly unfounded and should be dropped; that nothing is said (page 36) about Thurser [giants] but that only Grendel is called a thyrs, and that Beowulf did not request to have his splendid weapons, the work of Weland, with him in the grave, but asked that they be sent home to King Hygelāc.

The sixth song, ${ }^{\text {xii }}$ which contains Hroðgar's welcome, is particularly notable because of the Wilfings or Wylfings mentioned there, since according to the rule (Vulf for Ulf, Vord for Ord and still in Jutland, Volle for $\mathrm{Ole}$ ) it must be the same ones as the Icelanders called Ylfings, and these are perhaps the same as the famous Volsungs. However, the [Hroðgar's] speech is so short that it can yield no certainty, but how the reviewer can get the idea that by Wylfings shall be understood Norwegians is to me incomprehensible. The reviewer has done well not to take up the contradiction in the translation that Beowulf's father surrendered himself to the Wylfings so as not to be threatened by them and was then off to Denmark; but that he was none the wiser for this about the story is seen from the fact that he talks about Ecgpeow's wars with the Wylfings and that how

${ }^{10}$ No goddess appears in this passage. Grundtvig's confusion is again rooted in Thorkelin's incorrect Latin paraphrase of Beowulf, lines 31-19 (page 26 in Thorkelin), itself based on a faulty transcription of the lines. Grundtvig also assumes that it is Hildr, instead of the coastguard, who offers a blessing of protection to Beowulf and his men. 
Hroðgar sent the Wylfings his treasure. About that, the skald | Col. 1001 says nothing: he says only that Ecgpēow became Heaðolāf's killer (HAND BONAN, see 101 and 186) and therefore could not get along with the Wilfings and had to flee to Denmark. Afterwards he is reconciled with the Wylfings over the wergild, which Hroðgar paid, and for this, as it seems, Ecgpèow swore him allegiance and troops. However, perhaps the talk is just about an oath of indebtedness, which agrees best with the idea that he seems to have been a man of the Skjoldungs (AR SCYLDINGA) in times past.

Of the eighth and ninth songs [lines 499-558, 559-661] much could be said, but as they really are to some extent quite obscure, and I myself am still not entirely clear about their contents, I will only say that the reviewer should not so quickly say: "Beowulf had made an expedition to the island of Ræmas, then from there to the Land of the Brondings, where he plundered an independent town, and Bēanstān's son paid him off" for none of this appears in the poem. I am reluctant as yet to say for certain what Ramas means here, but grammar and context irrefutably show us that it does not belong to Holm in the next line and that it is clear that it was not Beowulf who went to the land of the Brondings; whether it was one Bjotal [Brecca], a son of Bēanstān, I am unwilling to conclude; but it is certain that the payment Bēanstān's son gave to Beowulf - according to Unferð’s opinion - was not praise-worthy, for Unferð pokes fun at it, and certainly even the Latin translator himself means, by his persolvit [he pays], neither silver nor gold. This is noted only so that no one will be looking for Ræmas-holm or think that Unferð talked about Beowulf's victories.

The tenth, eleventh and twelfth songs [lines 662-709, 710-790, 791-836] describe Beowulf's night watch and fight with Grendel; they have great poetic worth, but of course they are not really historic and are in places rather obscure. However, one can see that after the death of the king, the queen did not visit the guard again, that, after having swallowed a number of Beowulf's warriors, Grendel did not realize that he could do nothing against the strangers; and it is not this bad even in the Latin. When the reviewer further says that Beowulf pursued Grendel to the marshes, and that Hel [goddess of Norse Mythology] imprisoned him who had been the strongest among men, it is clear that he [the reviewer] is making this up himself for neither in the text nor in the translation does any such thing appear, which would also contradict the whole story. The text clearly reports that Grendel was in Col. 1002 the grasp of the strongest man 
among the children of men. (5 Strange, too, is the reviewer's ascribing Beowulf's recovery to the woolen coat; for, not to mention that this error undoubtedly belongs to the Latin translator, it is nevertheless certain that he [the translator] has no part in the ridiculous magical powers of the wool garments, because he says in the text that Hilda laid her hand on the hero's shoulders and therewith healed them. I would like to add that Hilda being praised here is just as awkward as the inclusion of the wool tunic, but since it does not help at all to renounce our heathen fathers' superstition, it seems to me that in cases of doubt one should even allow them to pin their faith upon a self-invented goddess rather than upon a woolen cloth, especially when it is a question of healing bloody flesh. That there are nowadays people who expect more help from a wool shirt than from all heavenly powers proves nothing, for there is a difference between blind pagans and enlightened folk.

4) That burg, byrig, beorg, biorh, - words which all derive from beorgan (bjerge, forvare [to take care of]) must, according to context, sometimes be translated as fortress or city, sometimes as grave, grave mound, just as, sometimes, mountain, is something which every Anglo-Saxon history book and dictionary immediately teaches.

5) It is the translator's "inferno captum" [captive in hell] that gave the reviewer ground for that awful rendering; but what use is it to try to correct what one does not understand?

(Continued)

\section{No. 64, Cols. 1009-1015}

The thirteenth song [lines 837-924] describes the happy morning gathering in the hall. The skalds and saga-tellers competed to glorify Beowulf by bringing to mind the main heroes of olden times, and they placed Beowulf above them all. Now, when one reads with the reviewer, "I heard (says the skald) many unknown deeds well sung," it is quite right that the skald says such things as this, but he [the skald] does not say that he himself was physically in the hall. But when one sees that the reviewer does not provide a word about the poem's contents, and one knows that the skald actually said many things about this, one must respond with a smile that the reviewer could have spared his comment. Certainly I do not now 
dare say that I understand everything that the skald says; in an important location a missing word places an unpleasant difficulty in the way of the interpreter; but I dare say that in this section Sigurd Fafnisbane is spoken about. Certainly he is not called by this name, but when one sees that the speech is about a hero who slew the dragon, took its treasures and became the most famous hero in the world, those of us who know the Volsung poems must immediately have our thoughts fall to Sigurd. When one sees the hero is called Sigmund's son (sigemunde GeSPRONG [arose from Sigemund]) then one doubts no longer, and the name Volse's relative (wæLSES EAFERA [Wæl's offspring]) makes the matter irrefutable; for the father of the Volsungs should be most reasonably called Volse and not Volsung | Col. 1010, just as Skjold, Yngve, Skelfes, etc. More obscure is the speech about Heremōd because we have no known song about him as a man, but it is strange that he is mentioned in "Hyndla's Song" (stanza 2) next to Sigmund Volsung, where it is said that Odin gave Heremōd a helmet and a coat of mail and Sigmund a sword (the renowned Gram). ${ }^{\text {xiii }}$ [When] Torfaeus says there were some unpublished verses about Heremōd, does he mean verses other than these, and are these verses still at hand? ${ }^{\text {xiv }}$ [If so,] then they might cast light over the closing of the thirteenth song and, better still, over the twenty-fourth and twenty-fifth [songs] where Hroðgar such much about Heremōd that is hard to understand.

About the scanty content list of the fourteenth and fifteenth songs [lines 925-990, 991-1049] I will only say in passing that it is pretty much the same, as good as worthless and even then not without errors, for Hroðgar stood not in any tower but on the floor or perhaps in a place of prominence in the hall (ON STAPOLE [on a flight of steps or a pedestal]) where he praised Beowulf and did not give him Healfdene's sword but himself is called "BRAND HEALFDANEs" [sword of Healfdene]. The gifts were actually a costly, gold-woven banner, a sword with gilded hilt, a helmet, and a coat of mail.

The sixteenth, seventeenth, and eighteenth songs [lines 1050-1124, 11251191, 1192-1250] describe the two previous feasts in Hroðgar's hall after the mutilation and flight of Grendel; they have been endowed with remarkable historical content. Now it is obvious that when a skald bases his story on events that in | Col. 1011 his days were well known but have since been lost from memory, then is it not easy to understand him fully, but being cautious about grossly misunderstanding one can still [come close] when you 
know his language and pay attention to his words. I will save my guesses about the war party mentioned in the sixteenth and seventeenth songs, but it is clear here that not a single comment is made about how Hroðgar staged a war party against the Frisians, about which, however, the reviewer so confidently speaks. Under Hroðgar's father, Healfdene, a war party occurred; whether or not the king himself was involved is unclear. But it is certain that a Hengest with his Frisians followed the Danish army and is referred to as the actual chieftain. The war party went not to Frisia, but doubtlessly to Sweden (sveo LOpe 85). ${ }^{11}$ The queen Hildeburh had married Finn, the chieftain of the Jutes, but he had to flee after the first battle, and he fell the following year when Hengest attacked him in his own country. I won't say more now about this so that I don't say too much. If this is the truth, one sees easily that neither the translator nor the reviewer understood what they were discussing, and to show this is the main thing here.

I will not talk here about the obscure passage in the beginning of the eighteenth song where the Brōsinga-Mene (without doubt Freya's Brysinga-Mene of the Icelanders) is briefly mentioned, but I must say that it is clearly pointless when the reviewer says: "The Goth Hygelāc got this ring from the son of Sverting's grandson, who fell when he tried to avenge himself on the Frisians." The speech here has nothing to do with BrōsingaMene, but about the necklace that the queen gave to Beowulf and that Beowulf later gave to Hygelāc. It is stated here that the jewelry was owned by the Goth King Hygelāc, the kinsman of Sverting, when he arrogantly seized Friesland and fell on the battlefield. A full account of this event is given in the thirty-third song (page 176).

I will not dwell here on songs nineteen through twenty-three [lines 1251-1320, 1321-1382, 1383-1472, 1473-1556, 1557-1650]. That Grendel's mother tried to avenge her son, killed Æschere, was pursued to her home in the marshes, was killed along with her son by Beowulf with a giant sword - these are the backbone events of the song's content, events that were not to be misjudged and the reviewer has not come up with anything else. Not even here is his explanation free from blunders, but they are not important enough to be reproached.

11 Grundtvig takes this phrase from Thorkelin's mistaken transcription of the manuscript word "sweolope" (of the heat or flames) at 1115 into two words. 
In the twenty-fourth song [lines 1651-1739], Beowulf does indeed tell about | Col. 1012 his heroic deeds with the giant sword, but he didn't give Hroðgar the sword, for it was, as he says himself, melted by the hot troll blood, leaving only the hilt upon which stood the remarkable runes. Hrodgar also appropriately gives very a long speech of thanks to Beowulf. However, [the fact] that he here put Beowulf's deeds high above Heremōd's and told about that hero's sad fate is absent from both the Latin translation and the review. In order not to say anything uncertain, I also defer further discussion about this obscure, but highly remarkable matter.

Beowulf's and Hroðgar's leave-taking speeches in the twenty-sixth song [lines 1817-1887] are, to my thinking, not so easy to follow, because one also must find the king's son's foreign travel entirely dubious and the quarrel between the Goths and the Spear-Danes exceedingly unreliable. Therefore, I am in the situation that I don't dare say as much as the reviewer and will only notice that Hroðgar, as a genuine Danish king, gave to Beowulf not just gold and shiny jewels but the most honorable and rarest stones in the crown: fervent love. ${ }^{12}$

See, the tears flowed down

On the old man's cheeks.

He could not conceal

His deeply moved mind,

Embraced Beowulf,

As friend hugs his friend,

And kissed him with warmth,

The glorious lad.

Here ends the song's first section, which tells about Beowulf's journey to and deeds in our Denmark.

The twenty-seventh song [lines 1888-1962], which delightfully describes Beowulf's journey home, in the end tells about Hyġelāc's marriage with Hæref's daughter, and the truth is that many various obscure words can be found in it. However, it was still a pity, as the Latin translator turned the queen into a bloodthirsty monster who had to be sent home to her father in order to bring peace into the hall. This blunder is quite inexcusable,

12 The passage is a translation of lines $1870-73$ of Beowulf. 
because in the following song and even in the translation itself (page 149) it clearly states that Hæreð's daughter poured out drink for Beowulf and loved his stalwart companions. This taught me straightaway that there might be something a little wrong with the harsh | Col. 1013 condemnation of her character. And upon examining the text, I found that the girl's entire crime was that for the love of Hygelāc she killed the monster that guarded her bower, and that none of Hygelāc's warriors dared approach. Then she did not go to but from her father's house with the young warrior, and they lived in happiness when Beowulf came, which is proved by the following text. Nevertheless, the reviewer confidently writes about the fair maiden: "She showed herself cruel and was hated, but when she went back over the yellow waves to her father's house, the king was once again loved."

I will not say much about the twenty-eighth song [lines 1963-2638], not because an important part of its contents is missing in the review but because I do not even know what the theme of this episode is, as some missing words obscure it. I will only say that a Frode is incorrect and that the text explicitly states that Hroðgar had promised his daughter to Frode's son.

Nearly the same thing happens with the twenty-ninth song [lines 20392092]: the reviewer has not pointed out several important parts of the contents, and many things are obviously wrong, but as even I am in doubt, I would rather note the point that Beowulf became king after Hygelāc (and Heardrēe, Hig̈elāk's son) and reigned happily for fifty winters until the dragon began to rage, [events] which have clear testimony in the text.

The reviewer says that the thirtieth and thirty-first songs are lost; however, the editor says (in the forward, page 18) that the twenty-ninth and thirtieth songs were joined in the manuscript with the twenty-eighth song, and he would not separate them. ${ }^{13}$ Now, as the editor has certainly split the twenty-ninth song from the twenty-eighth, but in contrast, not mentioned the thirtieth and the thirty-first, he must mean that these two are merged with the twenty-ninth song. Now such merging can well seem worrying, especially when the twenty-ninth song is not unusually long, but the editor's word must however vouch for [the fact] that in the manu-

${ }^{13}$ Even in recent editions of the poem, the placement of section thirty is conjectural, because the manuscript sectional divisions are confused at this point. Editors frequently mark section thirty as beginning at line 2093 and ending at 2143. Section thirty is normally thought to begin at line 2144 and section thirty-two at line 2221 . 
script there was no break between the twenty-ninth and thirty-second songs, and also that either three songs are merged together or the thirtieth song by some carelessness [is] called the thirty-second, which is not strange in such a poor manuscript. As far as one can see in these gaps, there isn't the slightest sign that either one or two songs might be missing, and it is even easy to guess that the words that the reviewer proposes to be certain are speculative.

| Col. 1014 By contrast, no one should refuse to say that the thirty-second song [2221-2311] with its many gaps is very obscure, and in the best of situations none of these gaps can be filled (especially at the end of the twenty-ninth song). We will never get to know the connection between the dragon and his treasure, but so much one can see straightaway both in the text and the Latin translation that an old king had hidden his treasure and put the dragon to brood over it. For three-hundred years the dragon lay as if he were slumbering, but then it happened that someone stole a silver dish from the treasure, and then the dragon woke and began to rage with poison and fire.

The reviewer quite correctly says that the thirty-third song [lines 23122390] begins with the story of the dragon's rampage and Beowulf's armament, and it not only seems but is evident that the skald goes back to talking about Hygelāc's fall, but then the reviewer becomes so confused that he realizes he has gone too far. Had he been so candid as to say: "Here the Latin contradicts itself, and as I do not understand Anglo-Saxon I cannot say for sure where the guilt lies" then I should be mostly lenient on him, but, upon my word, the high-born book-review-creature deserves some abuse.

Now, in brief, the thing is that Beowulf intended to go against the dragon, and now the skald says: "Many great deeds he had formerly done since the day he cleaned Hroðgar's hall and made war against Grendel's kin. It was not of the least of his battles when Hygelāc fell in Friesland." Now follows a speech about how Beowulf escaped, which, on account of holes [in the manuscript], is entirely unclear, but then it is said that when he came home to Gothland, the people offered him the throne because they were not confident that a child (Hygielāc's son) could defend the land. However, Beowulf would in no way be Heardrēd's (Hyġelāc's son's) lord, but would only rule the country until he became of age and could take over the sovereignty. Later on, Ōhtere's sons came (from Sweden as one later sees) from over the sea and killed Hygelāc 's son, but when he, Heardrēd, 
had died, Ongenpēow's son or ancestor (Ongenpēow was, as we later see, Ohtere's father) went back home again and allowed Beowulf to keep rule over the kingdom of the Goths.

The reviewer says correctly that the thirty-fourth song [lines 2391-2459] begins with the note that afterwards Beowulf traveled over the sea and avenged his king's death upon Ōhtere's | Col. 1015 son, but the transition is very unfortunate: "In this way he avenged shameful murder, when he together with eleven others fought against the dragon for it is written that he practiced heroic deeds until the day he went against the dragon." What's said here [about] the ship with the thirty men, etc., is nonsense, on which I will not dwell but hasten on to Beowulf's speech, which he gave before the dragon fight began, and which is one of the most remarkable episodes in the poem, but the Latin translation [is] so mangled that there is no way to find neither sense nor beauty nor any narration. What follows is a brief overview of the speech: "I lived through many battles, "says Beowulf, "in my youth and remember them distinctly. I was seven years old when King Hrēðel took me from my father's house, fostered and gifted me honorably. The worst thing that happened was the fate of the king's children, for his sons were Herebeald and Нæðcyn and my Hyġelāc. The eldest fell by his brother's hand; Нæðcyn shot amiss and hit his beloved friend with an arrow from his hornbow. It was a dreadful thing for the people, who would not let the death go unavenged, but it was a sorrowful thing for the old king that his second son should end his young life on the gallows. Then he took up the harp and sang a sorrowful song about his son hanging on the gallows, as food for the ravens, and by doing so he saved Hæðcyn's life ( $35^{\text {th }}$ song [lines 2460-2601]). But great was his agony; he mourned Herebeald, and could however not hate his murderer. He died of sorrow and left Hæðcyn the land and country. Then war arose between the Goths and the Swedes when Ongenpēow and Ōhtere made war on Hæðcyn.”

In this something is unclear, which is partly clarified in one of the following episodes that complements it. Then, Beowulf speaks again about his manhood and says that he knew how, if he were younger, he would take hold of the dragon. He would not use a weapon, but grapple with the creature as he did Grendel. The fight now begins and is described beautifully and the song ends with Beowulf's men fleeing to the forest and leaving their lord alone in order to save their lives. 


\section{No. 65, Cols. 1025-1030}

In the thirty-sixth song [lines 2602-2693] there is a little historical episode about Ōhtere's son and his sword; I still don't entirely understand it. And as it is quite true that Wìglāf Wìhstān's son, the only one who remained faithful to his king, here speaks loyal words and hastens to help Beowulf. I will not remark further.

I would rather not comment about the thirty-seventh song [lines 26942751] where the Dragon's death and Beowulf's death wound are reported, but I will note that it is bitter-sweet, and that in it Beowulf does not mention some of his deeds, but recollects only his power and sighs that he does not have a son to whom he could entrust his glorious weapons.

The thirty-eighth song [lines 2752-2820] describes the wonderful things Wìgläf saw in the dragon's cave, his return to the dying king, and Beowulf's last speech—all exceedingly delightful.

Not even in the Latin can I find anything concerning the portion of the thirty-ninth song [lines 2821-2891] that tells how Beowulf's men abandoned the place where their king fell, but I must say that it is not correct and also note that nothing is said about Wìglāf's affectionate, powerful speech in which he berates the warriors for their flight, though he certainly did so.

The contents of the fortieth and forty-first songs [lines 2892-2945, 2946-3057] are presented in a way similar to the contents of the $34^{\text {th }}$ song- i.e. completely wrong. | Col. 1026 Wìglāf does not speak about the occasion for the last war party, namely the fight between the Franks and the Frisians, which is a topic that is at home nowhere; no, but Wìgläf sits and moans sorrowfully over Beowulf's body, and says: "Now we must wait for the feud when the king's death becomes rumor among the Franks and the Frisians, for from them we must await painful repayment for what Hyggelāc did in his attacks on Frisia. Of the Swedes," he continues, "I don't expect promises or justice, for we all know how Ongenpēow, Ōhtere's father, robbed Hæðcyn of his life at Hrefna Wudu. Then the Goths had to escape away to Hrefnes Holt without their lord. The enemy guarded them there and threatened in the morning to kill half of the men and let the other half hang on the gallows for fun. However, dawn consoled the grieving ones. Then they heard Hyġelāc's horn. He of noble descent came to help them with powerful warriors." 
With this the fortieth song ends, and in the forty-first more is told about the war between Hygelāc and Ongenpēow, but it is not clear enough that I can see with certainty whether or not there were two wars, the first fought in Hygelāc's and the other in Ongenpēow's land, or if Ongenpēow lost his life. On the other hand, it is rather clear that he had to bow to Hygielāc's earl Wulf Wonrēding and that when Hygielāc ascended the throne of the Goths, Hygelāc rewarded him [Wulf] and King Eofor mightily for their exploits in the Swedish war, and afterwards gave Eofor his only daughter.

From this we now see that where the editor and reviewer have made only one war in which Hyġelāc died | Col. 1027 there actually are three quite different ones: in the first the Swede Ongenpēow attacked the Goths, after the death of Hreððel. In this the fall of Hæðcyn took place and the kingdom fell to Hyġelāc. The second war was made by Hyġelāc on the Franks and Frisians, and in this he himself dies; in the third Ōhtere and his sons waged war upon Hygelāc's son Heardrēd who fell and was followed on the throne by Beowulf, Hyggelāc's nephew. This is not a minor contribution to the ancient history of Sweden.

Now that Wìglāf has remembered the old enmity which prophesized new warfare after Beowulf's departure, he asks the people to hasten to bury their mighty lord, and the treasure, he says, that cost him his life the blaze should consume with him. In few but deep tones, he speaks about the sorrow that will overshadow land and people, and he then walks with the crowd to Earnanæs.

The last two songs [42, lines 3058-3156; 43, lines 3157-3182] contain another speech by Wig̀lāf in which he regrets that Beowulf did not allow the dragon to lie upon the gold until the world's end, and he consecrates all the treasure to the bonfire, and the whole poem ends with the story about Beowulf's funeral pyre and grave mound, and, it seems, with a small portion of the praise song the skalds gave voice to the grave.

As I stated earlier, it was not at all my intention to cover all of the poem's poetic contents and its abundance but, only as far as I could manage, to set right the major mistakes which are found in the reviewer's list of contents.

It can now just as little be my intention here to say much about the poem's worth and its architecture or about what benefit is to be taken from it for the history of the North. The simple declaration of the contents and the songs coupled with the sample translation [that] I provided give the intelligent reader a better picture of the poem's singularity than 
a long explanation could, and this picture can only be illustrated through a quiet contemplation of the whole, which I shall try to make possible in a rhymed translation for those of my countrymen who do not have the opportunity to become acquainted with the original language. I will only say so much here, that the poem "Bjowulfs Drape" [The Heroic Poem of Beowulf], which is probably the most suitable name for it, is so unique of its kind that I dare not classify it with any of the poems we have from the North's ancient times, for in its plan and execution one traces genuine artistry here, if I may say so, which strangely $\mid$ Col. 1028 relates to the old Danish frankness and simplicity. The Eddic poems about the Volsungs and Niflungs are undoubtedly the nearest known kin, but they never will be regarded as brothers and sisters. Their loftiness and depth of feeling and meaning are wanting in Bjovulfs Drape. Therefore, the poem is not much like the heroic fragments, which possess coherence and unity only invisibly. It is a beautiful, tastefully ordered and ornamented whole, and if a skald in the childhood of art wanted to bring forth such a work, he had to make do with a worldly unity, letting everything move around the hero [and] having everything cast glory on him. So it is truly, and the poem is in every way Beowulf's spiritual monument of molten gold which shines from headland far away over the sea and announces to the watchful eye of the steersman the glory of the Sea-Goth, though it should not be denied that, to the skald's credit, it knows its own lowness under the heavens toward which it points.

However, I must interrupt a reflection which would here lead too far astray, and only add that [judging] from all the internal indications the skald was of Anglian kin, although I am well aware that this just as much complicates the history of the poem as it explains its conditions.

Now, regarding the historical benefits, my research in this piece has already taught me that it is still much too early to estimate it further; that to the contrary, it is in a good sense invaluable to everybody who loves history and particularly, one can quickly say, for us Danes. This is for certain. The reviewer has very rightly noted that this poem should end the debate about whether in the old days Danish was a name of honor for the neighboring folks, only I doubt whether this will happen within a short amount of time, for surely, the testimony of this poem was unneeded in so obvious a case. If one would not believe nearly all the chronicles of the Middle Ages and even the Normans and Dudo from St. Quintin, would one then believe an 
old nameless skald? Not even Suhm would dare to believe his own eyes, but let himself be convinced by the Swedish writers and by the haughty Norwegian Gerhard Skonning that the Danish name and people had always been insignificant things in the Nordic region. He admitted graciously but modestly and with incomprehensible gentleness that the Danes | Col. 1029 stemmed from Uppland in Sweden and were quite latecomers compared with the men from the mountains [i.e. the Norwegians]. Why would any of these men admit the truth, when by that they would lose the honor [of having the longest history], which even the great Hugo Grotius has given them black on white [i.e. in writing] to be their inheritance? ${ }^{\mathrm{xv}}$

Another thing which seems to me just as remarkable is that the Goths are portrayed as a powerful people in the North, as friends of the proper Danes but as hereditary enemies of the Swedes, for this is the view of the relationship between peoples of the ancient North which I, before I saw this poem, found myself compelled to take up after considering history, and which I announced in my view of Europe, without expecting that these days it should find more acceptance than my idea of the Danes in particular.

Finally the most historic question with regard to the names and events occurring in the poem is: how do these relate to what we know about the olden days of the Danes and Icelandic poems? It is easy to answer along with the reviewer that since the poem is concerned with times as distant as these, we cannot expect to find events confirmed in the Nordic records; but what kind of an answer is that? The reviewer dates the poem's events to the sixth century after Christ, and now one must ask if the Norse legends do not go back this far in time, if the Icelanders did not place their Odin before the birth of Christ, if Saxo does not place his Skjold many generations earlier? This evasive answer will not do at all. The lists of kings of both Heimskringla and Saxo must be brought out into the daylight; and if it can be proved that the poem refers to the same places as the chronicles do, relationships are also to be found, if the characters of the poem are not actually made up, because kings whose memory was maintained abroad could never be forgotten in the native country, provided a number of legends were preserved. Now, as far as the Gothic kings are concerned, we have no series of legends about them, but we do have them for Danish and Swedish kings; it is doubtful that we might be allowed to seek Ongenpēow and Ōhtere among the kings of Uppsala, but Scyld, Healfdene and Hroðgar must necessarily be sought among the Danes. Notice that we find 
right away both Scyld and Healfdene in Saxo, [and] we find two of | Col. 1030 Healfdene's sons named Roe and Helge; we find three in Bjovulfs Drape and two of them are called Hroðgar and Hālga; Hroðgar must certainly be the same as Saxo's Roe, as the later is the Icelander's Hroar, and more so since the only thing Saxo narrates about Roe, that he built a city, is also the only single achievement the skald tells us about Hroðgar. That Saxo writes nothing about Grendel is understandable enough, because it is clear that Beowulf's fight with him as well as with the dragon are at most folktales with mythical significance. However, it is remarkable that the familiar old legend of the troll in Issefjord who took taxes of a tenth of a ships' crews seems to have been used by the skald for Beowulf's honor, just as the monks did for St. Lucius'.

This must be enough for my purpose here. I will only note that the legends in Geoffrey of Monmouth about the Danish king Gvitlak [Chlochilaichus] and his war against Uther Pendragon in part seem to apply to Hygelāc, and Suhm's belief that he is the same as the Danish Kohilak, who according to Gregory of Tours fell in a battle against the Franks (like Hyġelāc) might likely be verified. ${ }^{\text {vii }}$ However, I will deal with this and many other matters be it the will of God that I shall carry out my plan to make a Danish translation of the whole poem with a historical introduction about the poem itself as well as the historical episodes.

Now also to say a word about the language: it is the Anglo-Saxon dialect which differs most from Danish, and when one sees that even this in some respects is more like Danish than Icelandic, one must strongly remember to give up the illusion that Danish grew out of Icelandic, which Gram claimed in vain, but which history and healthy reflection contradict, and which a thorough study of the Norse languages utterly destroys except among those who, echoing a certain Icelander, have made that [notion], as Gram says, into such a thesis and fixed opinion that they do not bother to move on. ${ }^{\text {xvii }}$

\section{Conclusion}

\section{No. 66, Cols. 1045-1047}

Just as I had closed these remarks, Litteratur-Tidende, No. 29, informed me that the reviewer was in just as extraordinary a hurry to interrupt me in my 
discourse as to discuss the lay he did not understand. He calls my speech full of bile, and others besides myself will see in this a demonstration that he has more bile than I, and my answer to this as well as to the accusation of dreaming up flighty ideas is only that abusive words do not bother me.

If the reviewer has the amiable hope that my rhyming translation will be an arbitrary paraphrase, let that be his problem, but as he has not ventured to call the trial translation bad, thus he would have done better to keep quiet about such things. There's no evidence other than a serious misconception, none of my few rhyming translations permitting. If, by the way, anyone calls such a translation, as that which I have begun here, a paraphrase, then I have nothing against that and if someone else can do it better I would appreciate it, for I have truly so much to do that I would not take upon myself so laborious a task, if I did not believe thereby to be doing fatherland a service. I well know it is the fashion to sneer at everything I do, but still it seems to me that this the reviewer, in whom I assume a man who nevertheless has a sense of seriousness and fairness, could leave to Secretary Molbech, in the backyard of Athene. ${ }^{\text {viii }}$

Where the poem's editor Mr. State Councilor Thorkelin is concerned, no one shall say that in my article that with a single word have I disparaged his genuine merit as the poem's transcriber and editor, but have only given his translation the character reference it deserves, without in any way taking the opportunity to say rude things to the old man.

Finally, concerning the reviewer and his | Col. 1046 assertion that he is in this matter guiltless and beyond reproach, then I must briefly report as follows. Had the reviewer said to us that he just merely wanted to report the poem's content as it allowed itself to be unlocked from the Latin translation, then I would just have said he would have done better to hesitate than to hasten, since only in extreme necessity should one disseminate something on the correctness of which one is ignorant. Now, to the contrary, instead of confessing his ignorance, the reviewer acts as though he had read the [Anglo-Saxon] text, even diverges in some places from the translation, and makes his own observations about the language and dialect of the [original] poem. Now, I say he must by necessity bear the same responsibility for his list of contents as for his historical observations, which were also permitted, quite extraordinarily, to be build upon a translation, the correctness of which one either could not or would not judge. 
On the contrary, this high-born creature will not, where it is needed, confess his lack of knowledge but carries on as if he understood everything perfectly well-this creature who with so many of the modest scholars of our time, and not least in the so-called Danske Litteratur-Tidende which has long outraged me and shown me - and I suppose many others - just this high-born and vain creature stuck right out of the aforementioned review. On such an important occasion, this could only increase the criticisms that foreigners make of us. This I would avert; this creature I wanted to expose in his nakedness; therefore, I turned from the old editor to the younger reviewer and pitilessly made known his ignorance of what he so hastily discussed, and I would be particularly delighted if I, on this occasion, could contribute something to the Litteratur-Tidende. Either it should hereafter strive towards a more dignified behavior, or immerse itself utterly in the contempt, which-except for a few honorable exceptions-it has for a long time made itself quite extraordinarily deserving.

The publisher of Litteratur-Tidende I have esteemed and honored for many years, as I should; indeed, in respect out of esteem for him, I have not even previously protested against the unseemly fact that I am the only author he allows to be crudely vilified and lied about in his journal, but I have never been able to count it to his credit to be the publisher of so pitiable a periodical, and after the relationship in which he, as such, has placed himself towards me, he certainly could not | Col. 1047 in the eyes of the world, expect that I should react gracefully to such a review in the journal, no matter who wrote it.

N.F.S. Grundtvig.

Bibliography

Works by Grundtvig

- (1815) “Et Par Ord om det nys udkomne angelsaxiske Digt" in Nyeste Skilderie af Kjøbenhavn 60, 1815, cols 945-952; 63, cols 998-1002; 64, cols 10091015; 65, cols 1025-1030; 66, cols. 1045-1047.

- (1815), "Nok et Par Ord om Bjovulfs Drape" in Nyeste Skilderie af Kjøbenhavn 70, cols 1105-1109; 71, cols 1121-1125; 72, cols 1139-1144.

- (1817), "Om Bjowulfs Drape eller det af Hr. Etatsraad Thorkelin 1815 udgivne angelsachsiske Digt" in Danne-Virke II, 207-289. 


\section{Mark Bradshaw Busbee}

\section{Works by other authors}

Anon (1815), "[Anmeldelse af De Danorum Rebus Gestis]", Dansk Litteratur-Tidende (1815), 26-27, 401-462.

Bjork, Robert E. (1996), “Grímur Jónsson Thorkelin's Preface to the First Edition of Beowulf, Scandinavian Studies 68 (1996), 291-320.

Bradley, S.A.J. (2008), A Life Recalled: An Anthology of Biographical Source-Texts, Aarhus, Aarhus University Press.

Campbell, Alistair (ed) (1962), The Chronicle of Ethelweard, London, Nelson.

Cooley, Franklin D. (1940), "Early Danish Criticism of Beowulf, English Literary History 7 (1940), 45-67.

Fulk, R.D., Robert E. Bjork and John D. Niles (ed). (2008), Klaeber's Beowulf and the Fight at Finnsburg, $4^{\text {th }}$ ed. (1922), Torronto, Buffalo and London, University of Toronto Press.

Gibson, Edmund (1692), Chronicon Saxonicum: Seu Annales Rerum in Anglia Praecipue Gestarum, Oxford, Theatro Sheld.

Gram, Hans (1743-4), Prøve af Danske Ord og Talemaader af det Engel-Saxishe Sprog forklarede, København, Det Kgl. Vajsenhus Forlag.

Haarder, Andreas (1988), “The Seven Beowulf Reviewers: Latest or Last Identifications", English Studies 69 (1988), 289-292.

- (1975), Beowulf: the Appeal of a Poem, København, Akademisk Forlag.

Hall, J. R. (1996), “The First Two Editions of Beowulf: Thorkelin's (1815) and Kemble's (1833)", The Editing of Old English: Papers from the 1990 Manchester Conference, edited by D. G. Scragg and Paul E. Szarmach, Cambridge, Cambridge University Press, 239-250.

Hollander, Lee M. (1990), "The Lay of Hyndla", The Poetic Edda, Austin, Texas, University of Texas Press.

Langebek, Jacob (1774), “Ælnoth’s Hist. S. Canuti Regis,” Scriptores Rerum Danicarum Medii Ævi, Vol. III, Copenhagen, Andr. Hart. Godiche.

Shippey, T. A. and Andreas Haarder (eds.) (1998), Beowulf: The Critical Heritage, London and New York, Routledge.

Suhm, Peter Frederik (1782), Historie af Danmark, vol. 1, København, Brødrene Berling.

- (1779), Tabeller til den Critiske Historie, København, Brødrene Berling.

Thorkelin, Grímur Jónsson (1815), De Danorum rebus gestis secul. III \& IV: Poëma Danicum dialecto Anglosaxonica : ex Bibliotheca Cottoniana Musaei Britannici 
I edidit versione lat. et indicibus auxit Grim. Johnson Thorkelin, København, Typis Th. E. Rangel.

Torfæus, Thormodus (1711), Historia rerum Norvegicarum, IV volumes, København, Joachim Schmittgen.

\section{Endnotes}

i Later that year, in September, Grundtvig published a second essay on Beowulf, titled "Nok et par ord om Bjovulf," in which he restates many of his arguments in "Et Par Ord," this time with grammatical and lexical support.

ii See Bjork (1996), Cooley (1940), and Hall (1996) for discussions of Thorkelin and his 1815 edition.

iii Andreas Haarder (1988) convincingly identified Müller (1776-1834) as the anonymous reviewer. Müller served as the editor of Dansk Litteratur-Tidende from 1805-1830. He was a leading scholar in the field of early Scandinavian literature and later became Bishop of Sjælland (1830-1834).

iv Translated selections from "Et Par Ord" appear with commentary in Shippey and Haarder (1998, 91-95). See Haarder (1975) for brief discussions of the article.

v Grundtvig borrowed this expression from his copy of the Old Testament book of Amos, where the profit says to the Jews, "I vare som en rygende Brand, der reddes af en Brynde" (You were like a smoking brand [piece of wood], that was pulled out of the burning.) (4:11). Grundtvig reused the expression in his extended essay on Beowulf, where he writes, "Det hele Digt [Beowulf] er en Brand udrevet af Ilden, en Guld Harpe fra Hedenold, hvis Strænge sprang, og hvis Skruer smelteede i Luen" (The entire poem is a brand [piece of wood or sword?] pulled from the fire, a golden harp from heathen times, with broken strings and with its stem melted by the heat, 1817, 271).

vi Grímur Jónsson Thorkelin (1752-1829) was an Icelandic-born scholar employed by the government to conduct his research on Beowulf. Johan Bülow (1751-1828) was the assistant to the Crown Prince Frederick VI and a generous supporter of scholarly research of ancient Danish literature.

vii This is the anonymous review appeared in Dansk Litteratur-Tidende (1815).

viii In its original form, "det er ikke nogen Salighedssag" is a common phrase in Lutheran literature of various kinds during the period.

ix The Chronicon Saxonicum, ed. Gibson (1692) is an important early version of The Anglo-Saxon Chronicle. The Chronicle (III. 3) of Æthelweard (ca. 1000) seems to be Grundtvig's chief analogue for his account of Scyld's arrival. See 


\section{Mark Bradshaw Busbee}

Campbell (1962, 32-33) for a translation. Matthew of Westminster (English writer, ca. 1250) was, during Grundtvig's time, incorrectly regarded as the author of Flores Historiarum (Flowers of History), a history of England that brings together a number of significant historical documents. (Roger of Wendover was the original creator of the work.) Symeon of Durham (died ca. 1130) authored historical works concerned with the history of the north, particularly about the Viking Invasions and the Norman Conquest of England. Neither of these two latter texts is considered an analogue to or source for Beowulf.

$\mathrm{x} \quad$ This phrase might be best understood as the love a country has for the king as father of the land, rather than as an expression of modern patriotism. The name "Fredegod" contains the element "Frede", which means peaceful and powerful. See Bradley (2008, 424-5): "Medieval sources associate the time of Frothi III with the period of Pax Augustana and therefore with the time of the Incarnation of Christ."

xi Grundtvig's source for Ælnoth's text was Langebek (III. 361). Ælnoth of Canterbury (c.1085-c.1122) was an English Benedictine who settled in Denmark and wrote a biography of King Cnut.

xii Grundtvig discusses songs six and seven (lines 371-498) in this paragraph.

xiii The reference here is to Hyndluljóð (The Lay of Hyndla) (strophe 2), an Old Icelandic poem preserved in the Flateyjarbók (Flatisland Book) (ca. 1375). See Hollander (1990, 129-136) for a translation.

xiv Thormodus Torfæus (1636-1719) was an Icelandic historian who wrote the first comprehensive history of Norway since Snori Sturluson's Heimskringla.

xv Peter Frederik Suhm's fourteen volume Historie af Danmark (1782-1828) and his Tabeller til den Critiske Historie af Danmark (1779) were two of Grundtvig's historical resources. Norwegian historian Gerhard Schøning (1722-1780) was Suhm's friend and collaborator. Dutch legal scholar Hugo Grotius (1583-1645) formulated the international society doctrine.

xvi Here, Grundtvig first speculates about the connection between Hygelāc and the historical king Chlochilaich in Gregory of Tours' History of the Franks (III. 3).

xvii Hans Gram (1685-1748) was a Danish historian who wrote an influential treatise on the Danish language.

xviii Christian Molbech (1783-1857) was a leading historian, philologist and lexicographer who published materials from early Danish writings. Molbech edited Athene (1813-17), a monthly periodical that featured articles in fields such as ancient Nordic literature, history, language, legend, and myth. 